\title{
A DISCURSIVIDADE NO/DO CORPO DE MISS(ES) - MUÇULMANA E MUNDO
}

\author{
Adriana Stela Bassini Edral \\ Ana Paula Andrade Assumpção \\ Luciane Botelho Martins
}

\begin{abstract}
RESUMO
Partindo do princípio de que o funcionamento discursivo no/do corpo revela a presença de valores sociais e ideológicos congruentes à cultura de um povo, propomos, a partir de discursos veiculados na mídia online sobre os concursos de beleza Miss Mundo e Miss Muçulmana, compreender de que forma o poder é simbolizado no corpo e que estratégias são usadas pela mídia ocidental e oriental, considerando os estudos de gênero.
\end{abstract}

PALAVRAS-CHAVE: corpo; discurso; cultura.

\section{Introdução}

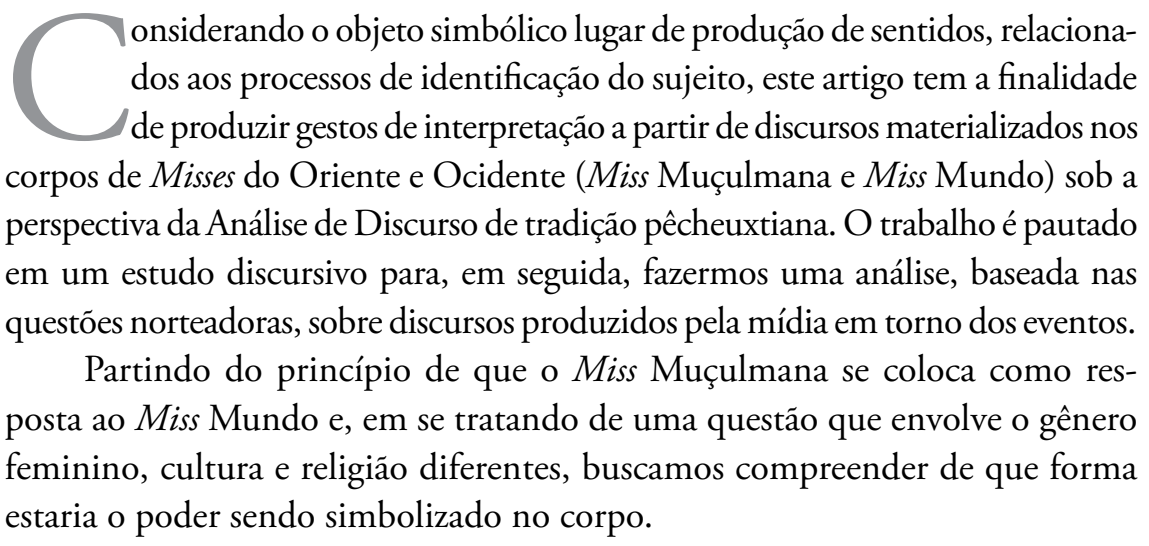




\section{Uma perspectiva ideológico-cultural ${ }^{1}$}

O espetáculo é regra, aparentemente, para os sentidos construídos no que se refere à história do mundo: parte-se não mais dos historiadores e das pesquisas metodologicamente validadas pela ciência para entender a história, mas sim do discurso midiático construído a partir da possibilidade técnica de reprodução dos meios de comunicação de massa. E se isto é, para Kehl (2004), o discurso possível diante da reprodutibilidade técnica e, assim, da indústria cultural, é desse ponto que se deve partir quando se fala de objetos culturais mediados pelos meios de comunicação de massa.

Em uma perspectiva mais frankfurtiana ${ }^{2}$, deve-se entender como o espetáculo se entrelaça com a indústria cultural. Para isso, percebe-se que os dois conceitos, um de Debord e outro de Adorno e Horkheimer, estão ligados à reprodutibilidade técnica: é a partir do momento em que a forma de fazer arte é permeada pela tecnologia que seu valor de exposição garante os efeitos da expansão da indústria cultural. Se antes a informação (ou a arte) era para poucos, hoje, como esses objetos são produzidos em série para os meios de comunicação de massa, há uma possibilidade de acesso por parte das massas urbanas e rurais. A Indústria Cultural - que, na visão de Canclini (1997), se dá a partir da cultura de massas - é para Arendt (1992) um fenômeno que se coloca sob uma condição: em vez de cultura, ela é o entretenimento de uma sociedade massificada imbuída de uma necessidade orgânica de se divertir. Adorno e Horkheimer possuem uma visão mais pessimista, afirmando que a ideia de necessidades orgânicas é apenas uma visão dos que se interessam em explicar o fenômeno da indústria cultural somente a partir da evolução tecnológica:

O contraste técnico entre poucos centros de produção e uma recepção dispersa condicionaria a organização e o planejamento pela direçáo. Os padrôes teriam resultado originalmente das

1 Em nosso entendimento, na perspectiva teórica da AD, a cultura ocupa um lugar de entremeio entre a história e o social, agindo como suporte para o funcionamento da ideologia.

2 Para Rüdiger (1999), são conhecidos como Frankfurtianos os filósofos adeptos à teoria crítica da Escola de Frankfurt, cujos fundamentos foram inspirados pela psicanálise e têm como principal característica os pensamentos marxistas. Suas teses se baseiam no comportamento sociopolítico e nas articulaçóes sociais diante do paradigma do capitalismo. Por sua visáo apocalíptica, também é conhecida como melancolia da esquerda. 
necessidades dos consumidores: eis porque são aceitos sem resistência. De fato, o que explica é o círculo da manipulação e da necessidade retroativa, no qual a unidade do sistema se orna cada vez mais coesa. [...] A racionalidade técnica hoje é a racionalidade da própria dominação. Ela é o caráter compulsivo da sociedade alienada de si mesma (ADORNO, HORKHEIMER, 1995, p. 114).

Em um pensamento apocalíptico, é perceptível que a indústria cultural, negócio pautado pelas leis capitalistas, é uma arma de alienação de uma sociedade condicionada pelos economicamente mais fortes, que sustentam um sistema que acaba por alienar o sujeito, isolá-lo, como quer Adorno (1995), em sua busca apenas de fins privados. A crítica aqui feita é relevante: a cultura de massas despolitiza o sujeito frente a todas as formas de se fazer produçóes pautadas pela máquina: a telenovela, a propaganda na revista, o jornalismo impresso e o digital. A capacidade política desse leitor, espectador - ou, sendo mais fiel aos frankfurtianos, consumidor -, é substituída pela subjetivação ilusória. Na opinião de Kehl, a mídia e seu mercado de produção de imagens trazem a ilusão de uma sustentação de si mesmo e da própria imagem ${ }^{3}$ a partir de sua dependência das imagens que, para Kehl (2004), o representam para si mesmo. E assim, estamos diante de um sujeito despolitizado, que se torna somente mais um pertencente a uma massa despolitizada e, por isso, renegada da faculdade de pensamento crítico que o espetáculo resiste e se sustenta na massa alienada. Para Kehl, a relação entre a indústria cultural e a sociedade do espetáculo é a impossibilidade de dissociação, isto é, há o que Pêcheux e Fuchs chamam de interpelação, ou o assujeitamento do sujeito como sujeito ideológico, isso se dá "de tal modo que cada um seja conduzido, sem se dar conta, e tendo a impressão de estar exercendo sua livre vontade" (1975, p. 165-166).

A sociedade está imbuída de espetáculo pelo consumo. Estamos, aqui, em um debate que diz respeito, acima de tudo, à identidade que estamos construindo do outro, o muçulmano. Em relação a essa percepção do outro,

3 Pensemos no sentido do "estádio do espelho", de Lacan: "uma identificação, no sentido pleno que a análise atribui a esse termo, ou seja, a transformação produzida no sujeito quando ele assume uma imagem - cuja predestinaçáo para esse efeito de fase é suficientemente indicada pelo uso, na teoria, do antigo termo imago" (1998, p. 1). 
não há como não entrecruzar com a sociedade do espetáculo. Para Derbod, estudioso que emplacou o termo,

...o espetáculo, compreendido na sua totalidade, é simultaneamente o resultado e o projeto do modo de produçáo existente. Ele não é um complemento ao mundo real, um adereço decorativo. É o coraçáo da irrealidade da sociedade real. Sob todas as suas formas particulares de informação ou propaganda, publicidade ou consumo direto do entretenimento, o espetáculo constitui o modelo presente na vida socialmente dominante (2003, p. 15).

Se ele, o espetáculo, é o resultado e o projeto do modo de produção existente, ele é, portanto, o resultado da indústria cultural. Nesse sentido, nos é permitido afirmar que o espetáculo, enquanto projeto, é pautado pelas leis capitalistas de produção de objetos culturais, o que reflete o conteúdo jornalístico em função da quantidade de laudas e de caracteres permitidos pela máquina de acordo com o interesse de cada notícia. Se se parte do pressuposto que uma notícia não é interessante para a massa, ela tem menos valor de exposição e, por isso, menos caracteres para ser redigida e publicada. E é esse corte a partir do capital que constrói o que Debord afirma ser a irrealidade social, pois se torna uma sociedade que se conhece a partir das imagens construídas sobre ela mesma, ou, no caso, sobre a vida do outro. Debord continua sua definição de espetáculo: "ele é a afirmação onipresente da escolha ${ }^{4} j a^{5}$ feita na produção, e no seu corolário - o consumo" (2003, p. 15). É o consumo que se resulta em descarte quase imediato. Nos termos de Arendt, é o consumo de objetos culturais não como fruição ou com fins de contemplação, mas sim como maneira de atrelar-se a uma posição social ou, como em Baudrillard (2011), uma percepção de si a partir de uma dinâmica social de necessidades, em que o consumo de objetos culturais é atrelado aos seus significados em relação a um sistema de valores. É desse sistema que, considerando a existência de um produto a ser produzido e vendido, a indústria cultural acaba por se esquivar no sujeito-consumidor

4 Convém lembrar que na perspectiva da $\mathrm{AD}$, essa escolha é ilusória, pois o sujeito é ideologicamente atravessado, acreditando ser ele a origem do dizer.

5 Grifo do autor. 
(leitor, espectador) de maneira que o poder de decisão se respalde nas próprias necessidades da empresa (ou, no caso, do meio de comunicação). Assim, o que ocorre é a mistificação do poder de escolha desse sujeito-consumidor, tendo acesso somente àquilo que o meio de comunicação se propôs a produzir. É esse o lugar da mídia brasileira: um sistema entranhado de processos que não se negam e funcionam de maneira naturalizada, tanto na mente do produtor de notícias quanto na mente do consumidor das mesmas. Assim, há que se perceber o lugar de discurso desses produtores de notícias: eles também participam de um sistema em que os interesses de suas pautas estão ligados ao que é vendável, na perspectiva do jornal (seja ele digital, impresso, eletrônico: todos passam pelo filtro da indústria), de maneira que a importância de sua matéria é diretamente proporcional ao número de caracteres a serem publicados; é o corte da máquina revelando a relevância da informação.

Nesse contexto, é sabido que o ocidente sabe pouco sobre os costumes do oriente e sobre o islamismo, a ver pela imediata relação entre a religião e todos os outros símbolos que nos remetem ao Oriente Médio. Pouco se sabe, por exemplo, sobre a presença do islamismo em países europeus e latino-americanos, bem como sobre a forte presença da religiáo (e de seus objetos culturais) na China, uma vez que esse último é visto, no senso comum, como um país unicamente budista e confucionista. Há que se perceber uma razão: o pouco acesso a esses assuntos que é dado à população ocidental pela mídia. Pensemos aqui uma breve percepção sobre os conteúdos jornalísticos cujo tema se relaciona com o concurso de beleza Miss Muçulmana, que teve sua primeira edição em 2011, em formato online. Para tanto, são analisadas notícias disponíveis na internet nos anos de 2013 e 2014 a respeito do concurso intitulado, em português, Miss Muçulmana.

É necessário entender a proposta desse concurso a partir do discurso de quem o criou, a World Muslimah Foundation - WMF, que tem como objetivo, de acordo com seu site, expandir a representação feminina na comunidade muçulmana. Aqui, fizemos uma tradução livre do texto de apresentação da fundação antes citada ${ }^{6}$ : Às mulheres confia-se trazer à vida as novas geraçóes. Isso significa que elas devem criar uma atmosfera de segurança, tranquilidade e estabilidade para seus filhos, bem como passar as virtudes

6 Disponível em: http://www.worldmuslimah.org/. Acesso em: 10 de janeiro de 2015. 
e valores que sáo essenciais para uma sociedade funcional. Por essa razão e muitas outras, uma mulher deve ser vista como uma pessoa igual e inteira com válidas contribuiçóes a fazer em qualquer nível da vida em comunidade e deve ser capaz de alcançar um certo nível refinado. Isso deveria ocorrer independente de qualquer raça, cultura ou crença religiosa, mas é especialmente importante em sociedade muçulmana. ${ }^{7}$

É a partir desse pressuposto que nasce a proposta do evento World Mulismah Award, que teve, em 2014, sua quarta edição e aconteceu em Yogykarta, na Indonésia. $\mathrm{O}$ evento trata de premiar a mulher muçulmana que se destaca em três categorias para avaliação: melhor citação do Al Qur'an (Alcorão), muçulmana mais talentosa e muçulmana mais criativa. É importante salientar que a grande final do concurso tem como etapas uma entrevista, que avalia inteligência em níveis intelectuais, espirituais e emocionais, bem como conhecimento e entendimento dos valores do islamismo. Também são critérios de avaliação a aparência e empatia. Para a contagem de pontos, também se inclui a escolha feita por votação por parte de crianças órfấs para as duas finalistas.

Do outro lado do mundo, no Ocidente, a repercussão midiática do evento teve lugar na internet por meio de notícias que anunciavam as vencedoras do concurso.

É necessário, aqui, em relação ao concurso no oriente, fazer algumas consideraçóes no que diz respeito ao título de quase todas as notícias: em absolutamente todas o nome do evento foi traduzido para o português como Miss Muçulmana ou Miss Mundo Muçulmano. Deve-se, de início, pensar essa tradução: não há, em absolutamente nenhuma outra fonte, o termo "miss" atrelado ao World Mulismah Awards, a não ser nos meios de comunicação ocidentais em formato online.

Para melhor explicar, tomam-se como objeto duas transcriçóes. A primeira é de uma notícia publicada em setembro de 2013, no site uol, intitulada

7 O texto original, em inglês: Women are instructed with bringing up the next generation. This means that they must create an atmosphere of security, tranquility and stability for their children while also passing down the virtues and values, which are essential for a functioning society. For this reason and many others, a woman must be seen as an equal and whole person with valid contributions to make at every level of community life and must be enabled to reach a certain refined level. This should occur regardless of race, culture or religious belief, but it is especially important in Muslim societies. 
Resposta islâmica ao Miss Mundo, Miss Muçulmana coroa nigeriana ${ }^{8}$ : Em meio a protestos de radicais islâmicos contra a realizaçáo do Miss Mundo na Indonésia, o país foi palco de realização de outro concurso de beleza. Nesta quarta-feira (18), o miss Muçulmana elegeu a mais bela mulher islâmica, em Jacarta. A vencedora foi a nigeriana Obabiyi Aishah Ajibola, escolhida dentre outras 20 finalistas. $\mathrm{Na}$ realidade, do total, 14 eram da Indonésia e as demais eram de Brunei, Malásia, Bangladesh, Irã e Nigéria. No último dia 13, a organizaçáo do concurso disse que a finalista dos EUA, Ainee Fatima, havia desistido da competiçáo. Ela alegou questáo de saúde na família. "Apesar de ser um concurso de beleza, seus requisitos sáo diferentes daqueles do Miss Mundo', disse a fundadora do concurso Eka Shanti. "A candidata tem que ser devota, ter um papel positivo e mostrar como equilibra a vida espiritual no mundo moderno atual", acrescenta. $O$ concurso acontece no mesmo país que recebe o Miss Mundo este ano. A Indonésia, de maioria muçulmana, tem sido palco de uma série de protestos radicais islâmicos contra a realizaçáo do Miss Mundo. Por causa das manifestaçóes, o concurso começou no último dia 8 sob um forte esquema de segurança.

A segunda transcrição, que tem como título Miss Mundo Muçulmano: a resposta do Isláo ao concurso Miss Mundo', é de um site de notícias de Portugal, o DN, e sua data de publicação foi novembro de 2014: Dezoito aspirantes a Miss concorreram ontem pelo título, num certame em que recitar o coráo e interpretar textos religiosos são algumas das provas. Náo há desfile de biquínis, prova de desporto e nem saltos altos. Em vez disso, há hijab (véu que cobre o cabelo e o pescoço da mulher, mas náo o rosto) e uma prova onde talento é sinônimo de recitar o Coráo com maestria. É assim o Miss Mundo Muçulmano, o concurso de beleza islâmico que surgiu em 2011 como uma resposta ao seu congênere Miss Mundo, e cuja final da quarta ediçáo foi disputada ontem à noite, na Indonésia. Uma médica e uma especialista em informática integravam o grupo de 18 aspirantes

8 Disponível em: http://noticias.uol.com.br/tabloide/ultimas-noticias/2013/09/18/resposta-islamica-ao-miss-mundo-miss-muculmana-coroa-nigeriana.htm. Acesso em: 10 de janeiro de 2015.

9 Disponível em: http://www.dn.pt/inicio/pessoas/interior.aspx?content_id=4254412\&seccao=ntv. Acesso em: 15 de janeiro de 2015. 
a miss, oriundas de países como Índia, Palestina, Egito, Irã, Alemanha e até Estados Unidos. Em comum? Todas eram muçulmanas, que é, aliás, um dos requisitos para tentar a sua sorte no certame. Saber interpretar os textos religiosos, recitar passagens do Corão, mostrar generosidade e modéstia, usar o hijab no dia a dia e ter opiniáo formada sobre várias questôes que concernem o Isláo [sic] e o seu papel no mundo moderno devem demonstrar durante as fases do Miss Mundo Muçulmano, cujas provas começaram em junho.

A primeira consideração é que nenhuma das notícias passou de 200 palavras. Isso pode ser justificável: o primeiro motivo é a própria plataforma - a internet - na qual a notícia está inserida. Em meio a tanto conteúdo, não há espaço para notícias longas, dado o caráter dinâmico da leitura no mundo virtual (ora, mas isso não é justamente sistema da indústria cultural determinando o tamanho da notícia?). Outro motivo seria a não proximidade do assunto com o ocidente: uma notícia de concurso de beleza muçulmano, que aconteceu em um país longe e sem concorrentes brasileiras ou portuguesas, teria pouca chance de passar de um relato, principalmente porque, no mundo capitalista, seria capital investido demais para se fazer uma cobertura mais aprofundada sobre um assunto que não tem proximidade cultural e nem geográfica com Portugal ou Brasil. Isso tudo, obviamente, são razóes suficientemente esclarecedoras sobre o modo de produção de notícias em qualquer lugar do mundo, mas a análise aqui feita não é ao modo de produção jornalística, pois se sabe que o jornalismo é um paradigma da modernidade e que nasceu da reprodutibilidade técnica. O que se questiona é se uma possível redução de espaço, pelas razóes acima descritas, resulta, possivelmente, numa redução de sentidos, ou melhor, numa nova construção de sentidos para o fato noticiado, baseado no que já foi dito sobre o islamismo. Benjamin (2012), em sua hipótese sobre a reprodutibilidade técnica, entende a reprodução dos fatos como a principal forma de perdê-los. Assim como a aura na arte, o fato se perde em função de sua reprodutibilidade, pois o que se quer da notícia é apenas sua visibilidade e não sua politização. E se é o espetáculo "uma relação social entre pessoas" (DEBORD, 2013, p. 14), muito mais importante para o noticiário é trazer a notícia à sua visibilidade construindo sentidos que se identifiquem com o sujeito-leitor. 
A segunda consideração é a versão em português do nome do evento e, assim, devemos explicar a tradução: o nome em inglês, divulgado no site oficial do evento, é World Mulismah Award. Em português, a tradução mais literal seria 'Premiação Mundial Muçulmana', ou 'Premiação da Muçulmana Mundial'. Mas não: é inserida a palavra miss no momento da tradução do nome do concurso para o mundo ocidental. Claramente, diante da palavra miss, termo utilizado em concursos de beleza feminina, questiona-se por que tal vocábulo foi inserido na tradução de um concurso que não trata de costumes ou cultura ocidental, mas sim de costumes religiosos orientais. Ou melhor: qual significado que essa palavra, vinda do espetáculo midiático ocidental, pode trazer ao leitor? Seria a redução do texto uma premissa técnica do sujeito jornalista com fins de trazer a esse evento um elemento que faz com que o leitor ocidental se identifique com o formato? O problema do termo miss é que seu significado para a cultura ocidental sugere sentidos que nos remetem à beleza, à perfeição do corpo feminino, e isso nos faz questionar a consequência de esse termo trazer uma série de significados que ele carrega quando se refere a um evento sobre costumes muçulmanos.

Uma última consideração também se dá sob a luz do espetáculo: ele, o espetáculo, não se importa em apresentar o concurso, suas peculiaridades e suas concorrentes. Ele brilha sob a luz da "resposta" de um grupo islâmico aos padróes ocidentais de beleza. Vejamos os dois títulos das notícias, que trazem a seguinte expressão: uma resposta ao Miss Mundo. Para inserir isso a um contexto, explica-se brevemente: o Miss Mundo, o mais antigo concurso de beleza que existe, foi lançado em 1951 e realizado na Inglaterra. Já na edição de 2013, o evento foi realizado em Bali, na Indonésia, e não foi bem recebido pela comunidade muçulmana do país. O mote do título, momento atraente para os olhos do leitor, traz todo foco de luz para o espetaculoso conflito entre os costumes ocidentais e mulçumanos, ou melhor, o (contra) ataque ao mundo ocidental. Assim, a mídia acaba por reforçar que o islamismo é aquele que nos ataca, que nos contradiz, que nos responde.

A partir disso, formulamos as seguintes questóes norteadoras: quais são as estratégias usadas pela mídia ocidental em oriental? Que significados o corpo das Misses produz sobre a perspectiva do gênero? E de que forma o "corpodiscurso" revela a interpelação ideológica? 


\section{Formas de significação no/do corpo das miss(es)}

Problematizar e analisar discursos em relação ao gênero é propor uma discussão que vai muito além das diferenças biológicas. Entendemos por gênero construçóes sociais calcadas na cultura, na história, na ideologia, nas relaçóes de poder e na religião, um conjunto de elementos que determina os sujeitos a partir de uma realidade que é simbólica ${ }^{10}$ e perpetuada por intermédio do discurso. Daí a importância da nossa proposta: analisar discursos produzidos por/ para mulheres no que se referem aos concursos/premiações de beleza.

De acordo com Murano e Boff (2002), as mulheres são sensíveis ao universo simbólico e espiritual, uma vez que são mais ligadas a pessoas que a objetos. É por isso que facilmente transformam os objetos em símbolos, assim como os atos em ritos. Enquanto isso, os homens estáo mais ligados a objetos que a pessoas. Isso explica suas práticas reificadoras, tudo em prol da manutenção do poder masculino sobre o feminino. Assim, para esses autores, no que se refere ao vestuário, "a vestimenta na mulher é um comentário da sua própria beleza. O que coloca no seu corpo se transforma em objeto de contemplação para si e para os outros" (2002, p. 50). Podemos perceber essa contemplação materializada em concursos de beleza, seja no ocidente ou no oriente.

Para fins de análise, tomemos dois enunciados verbais, que circulam nas redes sociais, referentes a matérias sobre concursos de Miss. O primeiro trata do concurso World Mulismah Award (Miss Muçulmana) e o segundo, do Miss Mundo: Obabiyi Aishah Ahibola, com um vestido e um véu em tons amarelos, foi coroada no final do concurso para muçulmanas, que decorreu num centro comercial de Jacarta, com participantes de seis países"11; A gaúcha Sancler venceu um dos concursos do Miss Mundo 2013, o Beach Beauty, ao ser considerada a candidata que tem o "melhor corpo"12.

10 Para Lacan, não temos, nem nunca teremos acesso ao real, assim, ao nos comunicarmos com o real por meio dos sentidos, operamos com representaçóes simbólicas, definido pelo autor como imaginário.

11 Retirado do site Jornal de Notícias datada em 19 de setembro de 2013. Disponível em: http://www.jn.pt/PaginaInicial/Mundo/Interior.aspx?content_id=3429337. Acesso em: 19 de janeiro de 2015.

12 Retirado do site G1, datada em 28 de setembro de 2013. Disponível em: http://g1.globo. $\mathrm{com} / \mathrm{mundo} /$ noticia/2013/09/candidata-das-filipinas-vence-miss-mundo-2013-na-indonesia.html. Acesso em 19 de janeiro de 2015. 
Observando os discursos aqui transcritos, notamos que há diferenças entre esses dois eventos. É claro que de concurso para concurso as regras, as etapas de seleção mudam, porém, o que nos chama atenção aqui são os saberes materializados nesses sujeitos (as candidatas), no corpo, por meio da dualidade entre "vestido e véu" versus "Beach Beauty e melhor corpo". O que nos interessa tratar entấo é do "corpodiscurso" (cf. Orlandi, 2012). Segundo a autora:

Não estaremos, pois, aqui pensando o corpo empírico, mas o corpo em sua materialidade significativa enquanto corpo de um sujeito. Não podemos pensar o sujeito, nessa perspectiva, sem a ideologia, e a ideologia sem a materialidade, a história e os processos da vida social e política. (ORLANDI, 2012, p. 85)

Assim sendo, por ser interpelado pela ideologia e pelo inconsciente, o corpo significa, produz efeitos de sentidos "estabelecidos e estabilizados" (ORLANDI, 2012, p. 93). Ou seja, conforme a autora, as imagens do corpo da mulher ocidental e da oriental são ideologicamente condicionadas ao social e político. Isso significa dizer que o sujeito se relaciona com seu corpo - atravessado pela memória ao mesmo tempo em que esse mesmo corpo se individualiza. Em seu artigo sobre as mulheres muçulmanas, Abu-Lughod (2012) dirá que o sujeito empírico veste a roupa apropriada para suas comunidades sociais e é determinado por padróes sociais, crenças religiosas e morais.

O uso de vestimentas faz parte de um processo de significaçáa, constituindo o poder e a distinção. Se formos analisar o tipo de roupa que as ocidentais utilizam, encontraremos uma infinitude: não há um padrão único de vestimenta, é o "corpo produzido pela ideologia capitalista" (ORLANDI, 2012, p. 95). Na perspectiva capitalista, temos o corpo feminino (objeto de desejo do outro), que consome ao mesmo tempo em que é consumido. Já no caso da mulher oriental, a muçulmana, um traço marcante é o corpo coberto por tecidos. Braços e pernas não podem aparecer e, muitas vezes, nem o rosto e nem os cabelos ficam visíveis. A beleza tem que ser escondida.

Quando nos deparamos com uma mulher usando o hijab (véu islâmico), percebemos que se trata de uma mulher muçulmana e nos vem logo um sentido de estranhamento e receio. No imaginário ocidental, o uso do véu (re)significa a submissão, o fanatismo religioso e até o terrorismo. Esse efeito 
imaginário se dá na relação entre o sujeito e o objeto simbólico, isso porque o corpo é investido de sentidos, ideologicamente falando. Segundo Ferreira (2013), o uso do véu representa uma perspectiva de empoderamento, identidade e religiosidade. Através de Fatema Mernissi ${ }^{13}$, Ferreira traz as dimensóes que o hijab apresenta: ocultação da visão; definição do acesso; referência à ética e moral. Em outras palavras, o véu, além de ser o reconhecimento da identidade de um grupo social e externar a religiosidade, também é uma forma de proteção: "o uso do hijab significa liberdade de sair à rua sem ter os olhos masculinos percorrendo seu corpo" (FERREIRA, 2013, p. 191). Cobrir-se com o véu é proteger-se dos olhares indesejados. Porém, essa "defesa" pode ter sentido inverso, conforme Žižek:

Com relação à mulher como um objeto de perturbação, quanto mais ela está coberta, mais nossa atenção (masculina) concentra-se nela e no que se encontra sob o véu. $\mathrm{O}$ talibã não apenas obrigou as mulheres a andar em público completamente cobertas, como as proibiu também de usar sapatos com saltos excessivamente sólidos (metal ou madeira), e ordenou-lhes andar sem produzir estalos muito altos que pudessem distrair os homens, perturbando sua paz interior e dedicação. É esse o paradoxo do gozo excessivo em sua forma mais pura: quanto mais o objeto é velado, mais intensamente perturbador é no mínimo traço de seu resíduo. (2010, p. 126-127).

O que Žižek chama de obrigação, proibição, os muçulmanos chamam de escolha. Ferreira aponta que a sociedade muçulmana interpreta que cabe à mulher decidir o uso ou não do véu e que se trata de uma determinação religiosa, mas que, caso ela não cumpra, deverá prestar contas de seus atos no dia do Juízo. Se a determinação é religiosa, a mulher tem o poder de decisão? Não há uma submissão à vontade de Deus?

Podemos afirmar que, nessa suposta escolha, temos uma das formas de silêncio - a censura. Segundo Orlandi, “a censura funciona não em nível de informação, mas de circulação e de elaboração histórica dos sentidos, assim como sobre o

13 A pesquisadora Fatema Mernissi foi citada no artigo Diálogos sobre o uso do véu (hijab): empoderamento, identidade e religiosidade, de Francirosy Ferreira. 
processo de identificação do sujeito em sua relação com os sentidos. Ela impede o trabalho histórico do sentido" (2007, p.107).

Assim, os sujeitos têm a ilusão de liberdade. No silêncio - que é do nível do interdiscurso - o sujeito se identifica com a formação discursiva, nesse caso específico, o discurso religioso. Althusser destaca que "a interpelação dos indivíduos como sujeitos supõe a 'existência' de um Outro Sujeito, Único, e central, em Nome do qual a ideologia religiosa interpela todos os indivíduos como sujeitos. Tudo isto está claramente escrito no que justamente se chama a "Escritura" (1985, p. 101 [grifos do autor]).

A ideologia religiosa submete os sujeitos ao Sujeito (Deus), garantindo a ordem por meio do "reconhecimento mútuo entre os sujeitos e o Sujeito, e entre os próprios sujeitos e, finalmente, o reconhecimento do sujeito por ele próprio" (ORLANDI, 2011, p. 242).

Sobre esse viés, retornemos ao texto da World Muslimah Foundation $W M F^{14}$-, que trata da representação da mulher muçulmana. Para ocupar a posição mulher muçulmana, esta precisa se enquadrar em um padrão, em saberes estabelecidos. Assim, repetiremos o texto para melhor visualizar nossos gestos de interpretação: Às mulheres confia-se trazer à vida as novas geraçóes. Isso significa que elas devem criar uma atmosfera de segurança, tranquilidade e estabilidade para seus filhos, bem como passar as virtudes e valores que sáo essenciais para uma sociedade funcional. Por essa razáo e muitas outras, uma mulher deve ser vista como uma pessoa igual e inteira com válidas contribuiçóes a fazer em qualquer nível da vida em comunidade e deve ser capaz de alcançar um certo nível refinado. Isso deveria ocorrer independente de qualquer raça, cultura ou crença religiosa, mas é especialmente importante em sociedade muçulmana.

Logo, o que nos chama atenção é o elemento linguístico confiar (verbo): incumbir, encarregar, acreditar, ter fé ${ }^{15}$. À mulher há a incumbência de gerar filhos - uma mentalidade concebida durante o ciclo patriarcal, assim como a sociedade escravista. Segundo Murano e Boff (2002), a redução da mulher à função procriadora está ligada à milenar educação a qual ela tem sido subme-

14 O texto World Muslimah Foundation - WMF faz uma apresentação da fundação que tem como objetivo promover um conceito de modelo da mulher muçulmana.

15 Dicionário online Michaelis: http://michaelis.uol.com.br/moderno/portugues/definicao/ confiar\%20_933089.html. 
tida - altruísmo e cuidado. Através da história, podemos perceber a mulher como produtora de cultura - uma cultura de apagamento e submissão, uma cultura com valor simbólico ao sagrado (ter fé): a mulher muçulmana é a geradora, a procriadora e encarregada de passar virtudes e valores aos filhos.

É pelo excesso de elementos linguísticos (substantivos abstratos e adjetivos) qualificadores da mulher muçulmana que os elementos essenciais a sua condição são revelados: instrumento de perpetuação de princípios morais e religiosos para/da comunidade muçulmana. De acordo com Ernst (2009), o conceito de excesso define-se como uma "estratégia discursiva que se caracteriza por aquilo que está demasiadamente presente no discurso" (p. 4), isto é, por meio da repetição de intensificadores (segurança, tranquilidade, estabilidade, virtudes, valores, essenciais, igual, inteira, válidas contribuições) são revelados saberes de uma determinada formação discursiva - Formação Discursiva Religiosa.

Esses princípios, de acordo com a Fundação, deveriam ser seguidos por todos - ocidentais e orientais -, visto o valor que têm para a comunidade que representam. A utilização do verbo "dever" no futuro do subjuntivo, ao mesmo tempo em que revela uma crítica (o não-dito ${ }^{16}$ ) à sociedade ocidental, reforça a posição-sujeito islâmica de assujeitamento ideológico às leis estabelecidas pelo livro alcorânico.

Desse modo, ao tomarmos os dois concursos, notamos que as concorrentes (tanto do Miss Muçulmana quanto do Miss Mundo) se apresentam com roupas luxuosas. O contraste, entretanto, dá-se na forma como o corpo é traduzido. No primeiro caso, o corpo é totalmente coberto, incluindo o véu como objeto simbólico, imprescindível para a participação no referido concurso, enquanto, no segundo, as silhuetas são valorizadas com vestidos justos e decotados ou ainda com biquínis, tornando-se ele próprio - o corpo - objeto simbólico de desejo do outro, a submissão ao "corpo perfeito" incentivado pelo capital de consumo. Porém, não seria também o concurso Miss Muçulmana uma forma de submissão?

\section{Para efeitos de conclusão}

Este artigo não teve a pretensão de apontar soluçóes para as questóes que envolvem semelhanças e diferenças entre os dois concursos, até porque

16 Conforme Orlandi (2013), há sempre no dizer um não-dizer que também significa. 
isso não cabe a nós, analistas de discurso, mas propor algumas reflexões sobre questôes de gênero relacionadas ao poder simbolizado no/do corpo, derivado de contexto sócio-histórico, e sobre como os sentidos são afetados pela sociedade: Oriente e Ocidente.

Embora a mídia disponibilize poucas informações sobre o evento, em se tratando de Análise de Discurso - $\mathrm{AD}$-, isso não se configura como obstáculo para a realização do trabalho. $\mathrm{O}$ excesso e os não-ditos produzem sentidos quando submetidos ao processo de leitura, já que a $\mathrm{AD}$ considera a opacidade da linguagem.

Podemos perceber, por meio de estratégias discursivas, que a crítica apresentada pelos idealizadores do concurso Miss muçulmana se dá principalmente pela exploração do corpo feminino desnudo em concursos de beleza ocidentais. Aparentemente controversos, os concursos/premiaçóes ou reduzem a mulher a objeto de consumo (segundo os moldes ocidentais) ou a instrumento de perpetuação de valores morais e religiosos (segundo os moldes islâmicos). Destarte, seja através da exposição das formas do corpo desnudo, seja pelo corpo coberto, incluindo aqui o véu, temos sujeitos ideologicamente assujeitados a serviço da sociedade que constituem.

\section{Referências}

ABU-LUGHOD, Lila. "As mulheres muçulmanas precisam realmente de salvação? Reflexões antropológicas sobre o relativismo cultural e seus $\mathrm{Ou}$ tros". Estudos Feministas, [S.1.], v. 20, n. 2, p. 451, ago. 2012. ISSN 0104026X. Disponível em: <https://periodicos.ufsc.br/index.php/ref/article/view/ S0104-026X2012000200006>. Acesso em 22 jan. 2015.

ADORNO, T.W.; HORKHEIMER, M. A dialética do esclarecimento. Rio de Janeiro: Jorge Zahar Editor, 1995.

ALTHUSSER, Louis. Aparelhos Ideológicos de Estado. Rio de Janeiro, RJ: Graal Editora, 1985.

BAUDRILLARD, J. A sociedade de consumo. Lisboa: Arte \& Comunicação. 2011.

BENJAMIN, W. Obras escolhidas: magia e técnica, arte e política. 3. ed. São Paulo: Brasiliense, 1987.

BUCCI, E.; KEHL, M.R. Videologias: ensaios sobre televisão. São Paulo: Boitempo, 2004. 
CANCLINI, N.G. Culturas híbridas: estratégias para entrar e sair da modernidade. Trad. Ana Regina e Heloísa Pezza Cintrão. São Paulo: USP, 1997.

DEBORD, G. A sociedade do espetáculo. E-book digitalizado por Coletivo Periferia e eBooks Brasil, 2003.

ERNST-PEREIRA, A. A falta, o excesso e o estranhamento. Seminário de Estudos em Análise do Discurso. UFRGS, 2009. Disponível em: <http://www. discurso.ufrgs.br/anaisdosead/4SEAD/SIMPOSIOS/AracyErnstPereira.pdf> Acesso em 25 de janeiro de 2015.

FERREIRA, F. C. B. Diálogos sobre o uso do véu (hijab): empoderamento, identidade e religiosidade. Perspectivas, São Paulo, v. 43, p. 183-198, 2013. Disponível em: http://seer.fclar.unesp.br/perspectivas/article/viewFile/6617/4864. Acesso em 23 jan. 2015.

LACAN, J. Escritos. Trad. Vera Ribeiro, Rio de Janeiro: Jorge Zahar Editora, 1998, P $96-103$.

MURANO, R.M. \& BOFF, Leonardo. Feminino e masculino: uma consciência para o encontro das diferenças. Rio de Janeiro; Sextante, 2002.

ORLANDI, Eni Puccinelli. As formas do silêncio. No movimento dos sentidos. $6^{\mathrm{a}}$ ed. Campinas: Unicamp, 2007.

. A linguagem e seu funcionamento: as formas do discurso. 4. ed. Campinas, SP: Pontes, 1996.

Pontes, 2012.

. Discurso em Análise: sujeito, sentido e ideologia. 2a ed. Campinas:

. Análise do discurso: princípios e procedimentos. Campinas: Pontes, 2013.

PÊCHEUX, Michel; FUCHS, Catherine (1975). A propósito da Análise Automática do Discurso: atualização e perspectivas. Tradução de Péricles Cunha. In: GADET, Françoise; HAK, Tony. (Org.). Por uma análise automática do discurso: uma introdução à obra de Michel Pêcheux. 3. ed. Campinas: Unicamp, 1997. p. 163-252.

RÜDIGER, F. Comunicação e teoria crítica da sociedade: Adorno e a Escola de Frankfurt. Porto Alegre: EDIPUCRS, 1999.

ŽIŽEK, Slavoj. Como ler Lacan. Trad. Maria Luiza X. de A. Borges. Rio de Janeiro: Zahar, 2010. 


\title{
THE DISCOURSIVITY IN/OF THE MISS(ES) BODY - MUSLIM $^{17}$ AND WORLD
}

\begin{abstract}
:
Assuming that the discursive functioning in/of the body revels the presence of social and ideological values, congruous to people's culture. We propound, from discourses aired by online media, about the beauty contest Miss World and Miss Muslim, understand in what way the power is symbolized in body, and what strategies has been used by occidental and oriental media, concerning gender studies.
\end{abstract}

KEYWORDS: body; discourse; culture.

Recebido em: 01/02/2016 Aprovado em: 18/07/2016

17 Neste trabalho, o termo Miss, de Miss Muçulmana, parte da tradução realizada pelos meios de comunicação ocidentais. 